Jurnal Ilmiah Magister Agribisnis, 1(2) 2019: 138-145,
Dol:

\title{
Analisis Produksi Jagung dengan Penyertaan Dana Penguatan Modal Lembaga Usaha Ekonomi Pedesaan di Provinsi Sumatera Utara
}

\author{
Analysis of Corn Production with the Inclusion of Capital \\ Strengthening Funds for Rural Economic Business Institutions in \\ North Sumatra Province
}

\author{
Ledy Festaria1), Rahmanta Ginting2), Muhammad Akbar Siregar ${ }^{3)}$ \\ 1) Program Studi Magister Agribisnis, Pascasarjana, Universitas Medan Area, Indonesia \\ 2) Departemen Agribisnis, Fakultas Pertanian, Universitas Sumatera Utara \\ 3) Magister Agribisnis, Pascasarjana, Universitas Medan Area
}

\begin{abstract}
Abstrak
Produksi dipengaruhi oleh suatu kombinasi dari banyak faktor antara lain luas lahan, pupuk, penyebaran varietas, tenaga kerja dan ketersediaan modal. Penelitian ini bertujuan untuk menganalisis apakah variabel luas lahan, luas penyebaran varietas dan modal (DPM LUEP) berpengaruh secara signifikan terhadap produksi jagung di Provinsi Sumatera Utara. Data yang digunakan dalam penelitian ini menggunakan data sekunder yang dimulai dari tahun 2011 - 2015. Data sekunder terdiri dari data luas lahan, luas penyebaran varietas dan pemberian modal (DPM LUEP) di 7 Kabupaten sentra produksi jagung. Data sekunder diperoleh dari Dinas Ketahanan Pangan dan Peternakan Provinsi Sumatera Utara, Dinas Tanaman Pangan dan Hortikultura dan Instansi terkait yang dianggap tepat. Metode analisis yang digunakan dalam penelitian ini menggunakan metode regresi berganda. Berdasarkan hasil penelitian, maka dapat diambil suatu kesimpulan bahwa secara keseluruhan model produksi jagung yang diestimasikan memberikan hasil yang signifikan, karena variable-variabel independen yaitu luas lahan, luas penyebaran varietas dan modal yang diamati signifikan dengan taraf nyata $\alpha=5 \%$. Variabel-variabel yang diamati mempunyai kesesuaian dengan ekspektasi teoritisnya.

Kata Kunci: Luas Lahan, Penyebaran Varietas, Modal dan Produksi Jagung.
\end{abstract}

\begin{abstract}
Production is influenced by a combination of many factors including land area, fertilizer, distribution of varieties, labor and capital availability. This study aims to analyze whether the variable of land area, width of the spread of varieties and capital (DPM-LUEP) significantly influence the corn production in North Sumatra Province. The data used in this study used secondary data starting from 2011 to 2015. Secondary data consisted of data of land area, extent of distribution of varieties and capital grant (DPM-LUEP) in 7 (seven) Regency of corn production center. Secondary data is obtained from Food and Livestock Service Department of North Sumatera Province, Food Crops and Horticulture Agency and related Institution which is deemed appropriate. The method of analysis used in this study using multiple regression method. Based on the result of the research, it can be concluded that the overall model of maize production is estimated to give significant result, because independent variables are land area, area of spread of varieties and capital that is observed significant with real level $\alpha=5 \%$. The observed variables are compatible with their theoretical expectations.
\end{abstract}

Keywords: Land Size, Distribution of Varieties, Capital and Production of Maize

How to Cite: Festaria, L, R. Ginting \& M. A. Siregar. (2019). Analisis Produksi Jagung dengan Penyertaan Dana Penguatan Modal Lembaga Usaha Ekonomi Pedesaan di Provinsi Sumatera Utara. Jurnal Ilmiah Magister Agribisnis, 1(2) 2019: 138-145,

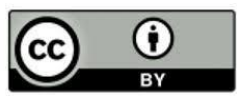




\section{PENDAHULUAN}

Jagung merupakan komoditas pangan kedua paling penting di Indonesia setelah padi tetapi jagung bukan merupakan produk utama dalam sektor pertanian. Jagung merupakan salah satu tanaman pangan pokok yang dikonsumsi oleh sebagian besar penduduk selain beras, ubi kayu, ubi jalar, tales dan sagu. Selain itu jagung juga bisa diolah menjadi aneka makanan yang merupakan sumber kalori dan juga sebagai pakan ternak. Sebagai produk antara penanaman padi, jagung juga diproduksi secara intensif di beberapa daerah di Indonesia yang merupakan penghasil jagung.

Kebutuhan jagung untuk bahan baku pakan ternak pada tahun 2018 diprediksi 8,5 juta ton, mengalami peningkatan dari tahun 2017 yakni 8 juta ton. Pemerintah menargetkan swasembada jagung dapat tercapai pada tahun 2017. Kondisi ini membuat budidaya jagung memiliki prospek yang sangat menjanjikan, baik dari segi permintaan maupun harga jualnya. Untuk merealisasikan hal tersebut pemerintah melakukan beberapa upaya diantaranya, melakukan kerjasama dengan pihak swasta yang bergerak di bidang industri pakan ternak dan makanan yang menggunakan jagung sebagai bahan bakunya. Sehingga pemerintah dalam usaha pengembangan tanaman jagung akan dikembangkan di daerah-daerah yang dikenal sebagai sentra produksi jagung dengan sistem rayonisasi. Daerah tersebut meliputi Sumatera Utara, Sumatra Selatan, Jawa Tengah, Jawa Timur dan Sulawesi Selatan.

Cara yang paling efektif dan efisien untuk memberdayakan ekonomi rakyat adalah mengembangkan kegiatan ekonomi yang menjadi tumpuan kehidupan ekonomi sebahagian besar rakyat yaitu sektor agribisnis. Saat ini, hanya pada sektor agribisnis Indonesia memungkinkan mampu bersaing untuk merebut peluang pasar pada era perdagangan bebas. Diluar sektor agribisnis, bukan hanya sulit bersaing tetapi tidak mampu memberdayakan ekonomi rakyat bahkan pemberdayaan ekonomi nasional. Rendahnya pendapatan petani yang umumnya mendiami wilayah pedesaan, juga menjadi penyebab terjadinya ketimpangan pendapatan antara desa - kota dan antara kawasan barat Indonesia dengan kawasan timur Indonesia (Saragih, 2001).

Sentra produksi jagung di Indonesia yaitu terdapat di Provinsi Jawa Timur, Jawa Tengah, Lampung, Sulawesi Selatan, Jawa Barat, Sumatera Utara dan Nusa Tenggara Timur (Badan Litbang Pertanian, 2005). Selama kurun waktu 2000-2009, pertumbuhan luas panen, produksi dan produktivitas jagung secara nasional menunjukkan peningkatan masing-masing sebesar 2,34\% / tahun, 7,03\% / tahun dan 4,52\% / tahun. Dengan demikian laju peningkatan produksi jagung nasional sangat dipengaruhi oleh faktor-faktor produksi dalam budidaya jagung nasional.

Secara nasional disparitas harga jagung pipilan cukup tinggi antar wilayah Indonesia. Tinggi rendahnya harga jagung tersebut tidak terkait dengan wilayah sentra produksi, namun lebih dipengaruhi oleh tinggi rendahnya permintaan/konsumsi jagung. Komoditas jagung dapat dipasarkan dari daerah sentra yang sedang panen ke daerah yang belum panen. Hal ini disebabkan karena pola tanam yang berlainan, karena pengaruh musim dan ketersediaan air dalam penanamannya. Demikian pula pergerakan harga jagung antar bulan cukup berfluktuasi. Fluktuasi harga jagung lazim terjadi 
Festaria, L, R. Ginting \& M. A. Siregar. Analisis Produksi Jagung dengan Penyertaan Dana Penguatan Modal Lembaga Usaha Ekonomi Pedesaan di Provinsi Sumatera Utara.

terutama disaat musim panen dimana harganya cenderung rendah, dan sebaliknya pada saat musim paceklik.

Dalam rangka mengatasi turunnya harga jagung yang seringkali terjadi pada saat panen raya, maka Pemerintah melalui Badan Ketahanan Pangan - Departemen Pertanian sejak 2003 telah membuat suatu kebijakan melalui penyaluran Dana Talangan (Bridging Fund) yang disebut juga Dana Penguatan Modal Lembaga Usaha Ekonomi Pedesaan (DPM-LUEP) kepada Lembaga Usaha Ekonomi di pedesaan untuk meningkatkan kemampuan dalam membeli gabah dari petani, khususnya pada saat panen raya dengan mengacu kepada Harga Pembelian Pemerintah (HPP). Selain itu, pengembangan pertanian dengan cara ekstensifikasi masih memungkinkan untuk kondisi di luar pulau Jawa. Namun tidak demikian untuk kondisi di pulau Jawa. Mengingat areal pertanian yang sudah sangat terbatas ditambah kepadatan penduduk yang terus meningkat dari tahun ke tahun. Perkembangan atau pertambahan produksi tidak lepas dari peranan faktor-faktor produksi atau input. (Mubyarto, 1989:89). Luas penguasaan lahan pertanian merupakan sesuatu yang sangat penting dalam proses produksi ataupun usaha tani dan usaha pertanian. Namun, penerapan teknologi juga sesuatu yang penting karena berhubungan dengan tingkat efisiensi (Moehar Daniel, 2004:56).

Untuk mendapatkan produksi yang tinggi, petani harus cermat dalam penggunaan faktor-faktor produksi usaha tani yang mempunyai hubungan terhadap tingkat produksi dan pendapatan yang diterima petani. Tanaman jagung sudah terkenal dan dibudidayakan sejak lama di Indonesia, bahkan dari pengembangan tanaman jagung telah menghasilkan beberapa varietas jagung unggul yang menghasilkan turunan jagung berumur panen singkat, buah besar, tongkol besar, dan manis kalau sudah bisa direbus atau diolah menjadi berbagai macam makanan. Hal tersebut didukung selain oleh lingkungan sebagai syarat tumbuh tanaman jagung memungkinkan tumbuh subur, juga lantaran pemeliharaan sampai reproduksi tanaman jagung relatif mudah dan sederhana. Tinggal lagi bagaimana perlakuan budidaya yang akan berimbas terhadap kuantitas dan kualitas produksi tanaman jagung.

Menurut Soedarsono (1998), fungsi produksi adalah hubungan teknis yang menghubungkan antara faktor produksi (input) dan hasil produksi (output). Disebut faktor produksi karena bersifat mutlak, supaya produksi dapat dijalankan untuk menghasilkan produk. Faktor produksi ini terdiri dari tiga komponen yaitu lahan, modal dan tenaga kerja. Begitu pula dengan usaha tani jagung dalam proses produksinya juga membutuhkan faktor-faktor produksi seperti tersebut di atas. Untuk memperoleh hasil maksimal maka dibutuhkan faktor produksi yang mencukupi dalam usaha taninya, sehingga para petani dapat memperoleh hasil yang optimal dan pada akhirnya dapat meningkatkan pendapatannya. Oleh karen itu penelitian ini bertujuan untuk mengetahui apakah luas lahan berpengaruh secara signifikan terhadap produksi jagung di Provinsi Sumatera Utara, mengetahui pengaruh penyebaran varietas berpengaruh secara signifikan terhadap produksi jagung di Provinsi Sumatera Utara, dan apakah modal (Dana Penguatan Modal kepada LUEP) berpengaruh secara signifikan terhadap produksi jagung di Provinsi Sumatera Utara. 


\section{METODE PENELITIAN}

Lokasi penelitian yang diambil adalah di Provinsi Sumatera Utara meliputi 7 Kabupaten/Kota sentra produksi jagung yakni Kabupaten Deli Serdang, Kabupaten Serdang Bedagai, Kabupaten Langkat, Kabupaten Karo, Kabupaten Simalungun, Kabupaten Dairi, dan Kabupaten Toba Samosir yang dilaksanakan pada bulan April 2017. Data yang digunakan dalam penelitian ini menggunakan data sekunder yang dimulai dari tahun 2011 - 2015. Data sekunder terdiri dari data luas lahan, luas penyebaran varietas dan pemberian modal (DPM LUEP) di 7 Kabupaten sentra produksi jagung. Data ini diperoleh dari Dinas Ketahanan Pangan dan Peternakan Provinsi Sumatera Utara, Dinas Tanaman Pangan dan Hortikultura dan Instansi terkait yang dianggap tepat.

Metode analisis yang digunakan dalam penelitian ini menggunakan metode regresi berganda sehingga analisis yang digunakan mengacu pada rumusan tujuan penelitian. Tujuan penelitian ini adalah menganalisis faktor-faktor modal, luas lahan dan penyebaran varietas terhadap hasil produksi jagung dan mengukur besarnya pengaruh masing-masing faktor tersebut. Analisis ini untuk mengetahui arah hubungan antara variabel independen dengan variabel dependen apakah masing-masing variabel independen berhubungan positif atau negatif dan untuk memprediksi nilai dari variabel dependen apabila nilai variabel independen mengalami kenaikan atau penurunan. Data yang digunakan biasanya berskala interval atau rasio. Persamaan regresi linear berganda sebagai berikut:

$\mathrm{Y}^{\prime}=\mathrm{a}+\mathrm{b} 1 \mathrm{X} 1+\mathrm{b} 2 \mathrm{X} 2+\mathrm{b} 3 \mathrm{X} 3$

Keterangan:

$Y^{\prime}$

$\mathrm{X} 1, \mathrm{X} 2$ dan X3

$=$ Produksi jagung

a

= Variabel independen

$\mathrm{b}$

= Konstanta (nilai Y' apabila X1, X2 = 0)

$=$ Koefisien regresi

\section{HASIL DAN PEMBAHASAN}

Pada model penelitian ini dilakukan uji ketetapan model dan uji asumsi klasik untuk mendaptkan model analisis terbaik. Pengujian model tersebut meliputi uji normalitas, uji multikolinearitas, uji heteroskedastsitas dan uji autokorelasi. Hasil uji menunjukkan bahwa model terbebas dari masalah asumsi klasik. Hasil analisis regresi akan dijelaskan dibawah ini.

Analisis Korelasi Ganda (R)

$\mathrm{R}$ dalam regresi linier berganda menunjukkan nilai korelasi berganda, yaitu korelasi antara dua atau lebih variabel independen terhadap variabel dependen. Nilai $R$ berkisar antara 0 sampai 1, jika mendekati 1 maka hubungan semakin erat, tetapi jika mendekati 0 maka hubungan semakin lemah. Angka $\mathrm{R}$ yang didapat 0,998 , artinya korelasi antara variabel luas lahan, luas penyebaran varietas dan modal (DPM-LUEP) terhadap produksi jagung sebesar 0,998 . Hal ini berarti terjadi hubungan yang sangat erat karena nilai mendekati 1 .

Analisis Determinasi (R2)

Kuadrat dari R menunjukkan koefisien determinasi. Angka ini akan diubah ke bentuk persen, yang artinya persentase sumbangan pengaruh variabel independen terhadap variabel dependen. Nilai R2 sebesar 0,997 artinya persentase sumbangan pengaruh variabel luas lahan, 
Festaria, L, R. Ginting \& M. A. Siregar. Analisis Produksi Jagung dengan Penyertaan Dana Penguatan Modal Lembaga Usaha Ekonomi Pedesaan di Provinsi Sumatera Utara.

penyebaran varietas dan modal terhadap produksi jagung sebesar 99,7\%, sedangkan sisanya dipengaruhi oleh variabel lain yang tidak dimasukkan dalam model ini.

Persamaan Regresi Linier Berganda

Persamaan regresi linier berganda dengan 3 variabel independen adalah sebagai berikut.

$$
\begin{aligned}
& Y^{\prime}=a+b 1 X 1+b 2 X 2+b 3 X 3 \\
& Y^{\prime}=-240.342,4+2,913 X 1+4,926 X 2+222,1 X 3
\end{aligned}
$$

Nilai konstanta (a) adalah - 240.342,4. Artinya jika luas lahan, penyebaran varietas dan modal nilainya adalah 0 , maka produksi jagung nilainya negatif yaitu - $240.342,4$. Nilai koefisien regresi variabel Luas Lahan (b1) bernilai positif, yaitu 2,913. Hal ini menjelaskan variabel luas lahan bersifat positif signifikan terhadap variabel produksi jagung. Artinya bahwa jika variabel independen lainnya nilainya tetap dan variabel Luas lahan mengalami kenaikan 1\%, maka produksi jagung akan mengalami peningkatan sebesar 2,913. Koefisien bernilai positif artinya terjadi hubungan positif antara luas lahan dengan produksi jagung, semakin naik luas lahan maka semakin naik produksi jagung.

Nilai koefisien regresi Luas penyebaran varietas (b2) bernilai positif, yaitu 4,926. Artinya bahwa setiap peningkatan luas penyebaran varietas sebesar $1 \%$ maka produksi jagung juga akan meningkat sebesar 4,926 dengan asumsi variabel independen lain nilainya tetap.

Nilai koefisien regresi variabel Modal (b3) bernilai positif, yaitu 222,1. Hal ini menjelaskan variabel modal bersifat positif signifikan terhadap variabel produksi jagung. Artinya bahwa jika variabel independen lainnya nilainya tetap dan variabel Modal mengalami kenaikan 1\%, maka produksi jagung akan mengalami peningkatan sebesar 222,1. Koefisien bernilai positif artinya terjadi hubungan positif antara modal dengan produksi jagung, semakin naik modal maka semakin naik produksi jagung.

\section{Pengujian Secara Bersama-sama}

Pengujian secara simultan digunakan untuk melihat bagaimana variabel independen secara bersama-sama atau simultan mempengaruhi variabel dependen. Dalam hal ini untuk mengetahui apakah variabel luas lahan, luas penyebaran varietas dan modal berpengaruh secara signifikan atau tidak terhadap produksi jagung. Pengujian ini menggunakan tingkat signifikansi 0,05. Langkah pertama yang dilakukan yaitu merumuskan hipotesis sebagai berikut.

Ho :Luas lahan, luas penyebaran varietas dan modal secara bersama-sama tidak berpengaruh terhadap produksi jagung.

Ha :Luas lahan, luas penyebaran varietas dan modal secara bersama-sama berpengaruh terhadap produksi jagung.

Dari pengujian koefisien korelasi diperoleh nilai F hitungnya sebesar 304,222 atau lebih besar dari $F$ tabel yaitu sebesar 9,277 pada tingkat kepercayaan 95\% ( $\alpha=5 \%$ ) dengan df 1 (jumlah variabel -1$)=3$, dan df $2(n-k-1)=3$. Jika $F$ hitung $\leq F$ tabel maka Ho diterima, jika $F$ hitung $\geq \mathrm{F}$ tabel maka Ho ditolak atau Ha diterima. Dengan demikian pada model persamaan ini variabel luas lahan, luas penyebaran varietas dan modal secara bersama-sama berpengaruh secara signifikan terhadap variabel produksi jagung.

\section{Pengujian Secara Parsial}

Penelitian ini dilakukan dengan analisis regresi berganda (multiple regression analysis), dengan memperhatikan nilai t hitung dari hasil regresi tersebut untuk mengetahui signifikansi variabel independen secara terpisah atau parsial terhadap variabel dependen pada tingkat alfa $=$ $5 \%$. Dengan syarat apabila variabel independen signifikan terhadap variabel dependen maka 
terdapat pengaruh antara variabel independen terhadap variabel dependen. Sedangkan apabila tidak signifikan maka tidak terdapat pengaruh antara variabel independen terhadap variabel dependen.

Pengujian koefisien regresi parsial atau uji t digunakan untuk menguji apakah hipotesis yang diajukan dalam penelitian ini diterima atau ditolak dengan mengetahui apakah variabel independen secara individual mempengaruhi variabel dependen. Dengan melihat t hitung pada print out komputer dan nilai t tabel pada tingkat kepercayaan 95 persen ( $\alpha=5$ persen) dan, hasil pengujian dapat dilihat pada Tabel 1 .

Tabel 1. Pengujian Koefisien Regresi Parsial (Uji t)

\begin{tabular}{cccc}
\hline Variabel Independen & t - hitung & T - tabel & Kesimpulan \\
\hline Luas Lahan & 4.115 & 3,182 & Signifikan \\
Luas Penyebaran Varietas & 5.123 & 3,182 & Signifikan \\
Modal (DPM-LUEP) & 3.658 & 3,182 & Signifikan \\
\hline
\end{tabular}

Sumber : Data Primer (diolah), 2017

Dengan melihat nilai t hitung yang kemudian diperbandingkan dengan nilai t tabel maka dapat diketahui secara parsial variabel independen signifikan atau tidak signifikan pada tingkat alfa 5 persen. Dengan memperhatikan Tabel 4.3. di atas diketahui bahwa nilai t hitung variabel luas lahan lebih besar daripada t tabel $4.115>3,182$ ) sehingga dapat dikatakan bahwa variabel luas lahan berpengaruh signifikan terhadap variabel produksi jagung. Adapun nilai t hitung variabel luas penyebaran varietas lebih besar daripada t tabel $(5.123>3,182)$ sehingga dapat dikatakan bahwa variabel luas penyebaran varietas berpengaruh signifikan terhadap variabel produksi jagung. Demikian juga dengan nilai t hitung variabel Modal lebih besar daripada t tabel (3.658 > 3,182) sehingga dapat dikatakan bahwa variabel Modal (DPM LUEP) berpengaruh signifikan terhadap variabel produksi jagung. Berdasarkan kriteria tersebut maka hasil pengujian hipotesis penelitian beserta keputusannya dapat dilihat pada Tabel 2 . di bawah ini.

Tabel 2. Uji Hipotesis dan Keputusan

\begin{tabular}{ccccc}
\hline Variabel Independen & $\mathbf{t}$ - hitung & T - tabel & Uji Hipotesis & Keputusan \\
\hline Luas Lahan & 4.115 & 3,182 & T hit $>$ t tabel & Ha diterima \\
$\begin{array}{c}\text { Luas Penyebaran } \\
\text { Varietas }\end{array}$ & 5.123 & 3,182 & T hit $>$ t tabel & Ha diterima \\
Modal (DPM-LUEP) & 3.658 & 3,182 & T hit $>$ t tabel & Ha diterima \\
\hline
\end{tabular}

Sumber : Data Primer (diolah), 2017

Berdasarkan Tabel 2. dapat diambil keputusan berdasarkan rumusan hipotesis penelitian yang diajukan. Pada variabel luas lahan, luas penyebaran varietas dan modal (DPM LUEP), karena t hit $>\mathrm{t}$ tabel, maka Ha dinyatakan diterima.

Pengaruh Luas Lahan Terhadap Produksi Jagung.

Pengaruh luas lahan terhadap produksi jagung secara parsial signifikan terhadap produksi jagung. Lahan pertanian merupakan penentu dari pengaruh komoditas pertanian. Secara umum dikatakan, semakin luas lahan (yang digarap/ditanami), semakin besar jumlah produksi yang dihasilkan oleh lahan tersebut (Abd. Rahim, 2007). Pengaruh luas lahan tidak hanya pada tingkat efisiensi usaha tani saja, tetapi juga mempunyai dampak pada upaya transfer dan penerapan teknologi dalam pembangunan pertanian. Bila pemilikan lahan lebih banyak 
Festaria, L, R. Ginting \& M. A. Siregar. Analisis Produksi Jagung dengan Penyertaan Dana Penguatan Modal Lembaga Usaha Ekonomi Pedesaan di Provinsi Sumatera Utara.

secara kotak-kotak dengan luas penguasaan yang sempit, upaya pembangunan pertanian akan sulit dilakukan. Tetapi bila penguasaan lahan cukup luas, proses transfer teknologi akan lebih mudah.

Tanah merupakan faktor kunci dalam usaha pertanian. Tanpa tanah rasanya mustahil usaha tani dapat dilakukan. Pengertian tanah di sini adalah bukan sekedar pada wujud nyata tanah saja, tetapi juga dikandung arti media di mana usaha tani dilakukan (Moehar, 2004). Produksi jagung erat kaitannya dengan input faktor-faktor produksi lainnya, artinya meskipun luas lahan yang besar tanpa diikuti dengan penambahan faktor produksi lainnya, seperti teknologi, bibit unggul, efisiensi tenaga kerja dll, maka akan berdampak terhadap produksinya. Karena semakin besar lahannya maka input faktor produksi yang lain juga akan semakin besar. Sehingga tentu saja akan mempengaruhi produksi jagung tersebut.

Efisiensi ekonomi merupakan pedoman bagi petani dalam mengalokasikan faktor-faktor produksi, sehingga dapat mencapai keuntungan maksimum. Dalam usaha tani dimaksudkan agar petani mengalokasikan sumber daya yang ada secara efektif dan efisien untuk tujuan memperoleh keuntungan tertinggi. Efisiensi ekonomi tertinggi akan menunjukkan bahwa produksi yang dihasilkan dalam suatu usaha tani sudah mencapai keuntungan yang maksimal.

Pengaruh Luas Penyebaran Verietas Terhadap Produksi Jagung.

Dalam pengelolaan sumberdaya produksi, salah satu aspek yang penting dalam intensifikasi sumberdaya pertanian adalah aspek varietas bibit tanaman. Dan hasil analisis regresi dapat diketahui bahwa faktor luas penyebaran varietas (b2) secara signifikan mempengaruhi produksi jagung, secara positif dalam model penelitian. Faktor produksi benih yang digunakan oleh petani akan menetukan besarnya kualitas dan kuantitas jagung yang dihasilkan oleh petani. Benih yang digunakan harus baru, bukan berasal dari hasil panen sebelumnya. Hasil panenan jagung sebenarnya masih dapat dipakai lagi sebagai benih untuk musim tanam berikutnya namun benih sudah tidak murni lagi sehingga hasilnya akan lebih rendah.

Penggunaan benih hibrida pada usahatani jagung akan meningkatkan produksi, dengan benih hibrida akan menjaga kemurnian sifat-sifat unggul benih tersebut, seperti tahan serangan penyakit, dapat menghasilkan tongkol yang sama besar dan tongkol tertutup rapat atau biji terisi penuh. Semakin luas penyebaran varietas unggul maka akan sangat berdampak terhadap produksi jagung yang dihasilkan oleh petani.

\section{Pengaruh Modal Terhadap Produksi Jagung.}

Modal adalah faktor terpenting dalam pertanian khususnya terkait bahan produksi dan biaya tenaga kerja. Dengan kata lain, keberadaan modal sangat menentukan tingkat atau macam teknologi yang diterapkan. Kekurangan modal menyebabkan kurangnya masukan yang diberikan sehingga menimbulkan resiko kegagalan atau rendahnya hasil yang akan diterima. Berdasarkan data hasil penelitian variabel modal menunjukkan pengaruh yang signifikan terhadap produksi jagung. Hal ini sesuai dengan teori Cobb Douglass yang menyatakan bahwa output produksi dipengaruhi oleh modal.

Dari ketiga variabel yang dikaji, pengaruh paling dominan terhadap hasil produksi jagung adalah oleh variabel modal sebesar 222,1. Bentuk pengaruh antara modal terhadap produksi jgung adalah pengaruh positif dan signifikan yang ditunjukkan dari koefisien regresi yang bertanda positif sesuai dengan teori. Dengan demikian dapat dijelaskan bahwa jika variabel modal ditingkatkan maka akan diikuti dengan meningkatnya produksi jagung.

Teknologi juga berperan dalam menentukan saling keterkaitan faktor produksi. Misalnya luas lahan yang digunakan satu hektar, maka berapa jumlah modal dan bibit unggul yang dibutuhkan dapat ditentukan dengan menetapkan teknologi yang akan diterapkan. Begitu juga kalau modal 
yang tersedia terbatas atau ditentukan maka luas usaha tani juga harus mengikuti. (Moehar, 2004). Disamping teknologi, kesuburan dan jenis tanah juga berpengaruh terhadap produksi jagung. Kesuburan dan jenis tanah akan memberikan atau mengarahkan petani pada kebijakan atau pilihan penggunaan pupuk dan pemupukan. Pupuk apa saja yang dibutuhkan dan berapa banyak, kapan diberikan serta berapa takaran setiap pemberian, dan dengan cara apa memberikan. Dengan ini semakin jelas manfaat diketahuinya jenis tanah dalam pengembangan usaha dibidang pertanian, dan cara bercocok tanam. (Moehar, 2004)

\section{SIMPULAN}

Secara keseluruhan model produksi jagung yang diestimasikan memberikan hasil yang signifikan, karena variabel-variabel independen yang diamati signifikan dengan taraf nyata $\alpha=5 \%$. Variabel-variabel yang diamati mempunyai kesesuaian dengan ekspektasi teoritisnya. Dimana luas lahan, luas penyebaran varietas dan modal mempengaruhi produksi jagung secara positif. Sumatera Utara memiliki peluang besar untuk meningkatkan produksi jagung karena memiliki sumber daya alam dan agroekologi yang mendukung serta keunggulan komparatif dan kompetitif baik sebagai substitusi impor maupun ekspor. Oleh karena itu diperlukan terobosan kebijakan untuk merealisasikan peluang ini melalui peningkatan efisiensi sistem komoditas jagung dengan mengembangkan sarana dan prasarana usaha tani dan ekonomi serta teknologi.

\section{DAFTAR PUSTAKA}

Anonimus. (2004). Pedoman Umum DPM-LUEP, Badan Bimas Ketahanan Pangan, Jakarta.

Anonimus. (2006). Petunjuk Pelaksanaan dan Tim Pembina serta Tim Teknis DPM-LUEP Tahun 2006 Badan Ketahanan Pangan Provinsi Sumatera Utara, Medan.

Anonimus. (2009). Petunjuk Pelaksanaan Kegiatan Pemberian Pinjaman Penguatan Modal bagi Lembaga Usaha Ekonomi Pedesaan (DPM-LUEP) Untuk Mengantisipasi dan Menjaga Stabilitas Harga Jagung di Tingkat Petani Tahun 2009 Provinsi Suamtera Utara, Medan.

Anonimus. (2012). Rencana Strategis dan Program Kerja Pemantapan Ketahanan Pangan Tahun 20132018, Badan Ketahanan Pangan Provinsi Sumatera Utara, Medan.

Anonimus. (2013). Evaluasi Program Ketahanan Pangan Provinsi Sumatera Utara Tahun 2013, Badan Ketahanan Pangan Provinsi Sumatera Utara, Medan.

Anonimus. (2016). Nutrient Deficiency in Corn. Laman Perbandingan Gejala Fisik Kekurangan Hara pad Jagung, Sebagai Pedoman Bagi Tanaman Serealia.

Daniel, Demonick, 2002. Ekonomi Pembangunan Pertanian, Erlangga, Jakarta

Departemen Pertanian. (2005). Balai Besar Penelitian \& Pengembangan Sumberdaya Lahan Pertanian. Badan Penelitian dan Pengembangan Pertanian. Balai Penelitian Tanah. Departemen Pertanian. Jakarta.

Mohar, Daniel. (2004). Pengantar Ekonomi pertanian. PT Bumi Aksara, Jakarta.

Mubyarto. (1989). Pengantar Ekonomi Pertanian. LP3S, Jakarta.

Saragih, Bungaran. (2001). Suara dari Bogor Membangun Sistem Agribisnis, PT. Loji Grafika Griya Sarana, Jakarta.

Soedarsono. (1998). Ekonomi Sumber Daya Manusia. Universitas Terbuka, Jakarta.

Soekartawi. (2005). Agribisnis Teori dan Aplikasinya, Raja Grafindo Persada, Jakarta.

Tjitrosoepomo, Gembong. (1991). Taksonomi Tumbuhan. Gadjah Mada University Press, Yogyakarta. 